\title{
Communication Model of Siak Children's Forum Cohesiveness in Actualizing Siak Child-Friendly City
}

\author{
${ }^{1}$ NOVA YOHANA, ${ }^{2}$ M. NOR, ${ }^{3}$ FITRI HARDIANTI, ${ }^{4}$ TUTI KHAIRANI HARAHAP
}

\begin{abstract}
${ }^{1}$ Jurusan Ilmu Komunikasi, Fakultas IImu Sosial IImu Politik, Universitas Riau,Kampus Bina Widya Jl. Hr.Soebrantas KM.12,5, 2 Prodi Pendidikan Fisika, Fakultas Keguruan Ilmu Pendidikan, Universitas Riau, Kampus Bina Widya Jl. Hr.Soebrantas KM.12,5, ${ }^{3}$ Jurusan Ilmu Komunikasi, Fakultas Ilmu Sosial Ilmu Politik, Universitas Riau Kampus Bina Widya Jl. Hr.Soebrantas KM.12,5, ${ }^{4}$ Prodi Administrasi Publik, Fakultas Ilmu Sosial Ilmu Politik, Kampus Bina Widya Jl. Hr.Soebrantas KM.12,5

email: 1nova.yo7@gmail.com, m.nor@lecturer.unri.ac.id _fitri.hardianti94@gmail.com, tuti.fisipunri@gmail.com
\end{abstract}

\begin{abstract}
The Siak Children's Forum (FASI) is a children's organization organized by the government of Siak Regency to bridge communication and interaction between government and children in order to fulfill the rights of children's participation and empowerment in a development policy program of Siak Regency as a child-friendly city. This study is conducted in order to inform and analyze the participation and communication of cohesiveness to achieve empowerment in a development policy of child-friendly city in Siak Regency. The research is qualitative with collecting data methods of observation, interviews, and documentation. The result objective of this research is to show the world that FASI as the sponsor for fulfilling and empowering children's' rights in participation is having an active participation to share and think of social participation and an interest in participation. FASI group cohesiveness is clearly seen from members' intensive interaction, loyalty and communication in the forum through face-to-face communication or virtual network communication of all channels as the efforts to actualize and fulfill children's rights in Siak Regency.
\end{abstract}

Keywords: Children's Forum, Communication Group cohesiveness, Child-Friendly City

\section{Introduction}

A child is seen as a mandate that must be constantly preserved, protected and fulfilled their basic rights, whether in the family, society or the state. Children are the future and next generation expected to continue the ideals of the nation, so that the state is obliged to fulfill the right of every child to be able to live, grow, develop and participate fairly in accordance with self and human dignity, as well as to protect them from acts of violence, exploitation, discrimination and other abuses. With the enactment of the Minister of Women Empowerment and Child Protection Regulation of Republic of Indonesia Number 11 Year 2011 on Policy Regency/ Child-Friendly City, children's rights would be a highlight of concern. Child-friendly city/regent (KLA) is a child rights-based development system through integrating the commitment and resources of governments, communities, and businesses which planned thoroughly and sustainably in policies, programs and activities for the fulfillment of children's rights. It means that all the needs related to the fulfillment of children's rights can be implemented through policy development program of child-friendly city/regency.

In a child-friendly environment, communities and residents are encouraged to develop a lifestyle that is friendly to children (child friendly lifestyle), so that children can grow and develop in a healthy and reasonable circumstances as a first step to actualize the vision of Indonesian children who are healthy, growing and developing, bright, cheerful, noble, protected and actively participate. (Yustikasari and Rosfiantika, 2012: 77). One of the principles of regency/city development policy for children is the child's participation in development.

Based on Law of Minister of State for Women's Empowerment and Child

Received: November 22, 2017, Revision: April 20, 2018, Accepted: June 04, 2018

Print ISSN: 0215-8175; Online ISSN: 2303-2499. DOI: http://dx.doi.org/10.29313/mimbar.v34i1.3222.138-146

Accredited B based on the decree No.040/P/2014, valid on February, 18, 2014 until February, 18, 2019. Indexed by DOAJ, Sinta, IPI 
Protection No. 3 of 2011 stated that the child participation in development policy was the template for ministry/Institutions in implementing programs and activities related to children's participation in development. Children's program participation is one of the policies that provide space and opportunities for children to express their aspirations, needs, interests, and desires in development. Therefore, one indicator of the actualization of child-friendly regency/city is the establishment of child participation programs, such as Children's Forum.

Children's forum is an organization or social institution that used as a medium or social order for children aged 18 years whose members are representatives of the group of children or groups of children's activities that managed by children and nurtured by the government as a medium to listen and meet the aspirations, voice, opinions, desires, and needs of children in the development process (Deputy children's growth and development ministries of Women's Empowerment and child protection, 2012: 21). Children's forum as a medium or institution of children's participation facilitated by government has gradual existence of National Children's Forum (FAN), the Regional Children's Forum (FAD), Children's Forum of District level, Subdistrict Level Children's Forum, and the Forum of Children's Village Level.

Siak Children's Forum (FASI) is one of the active forums situated in Siak, Riau Province. Siak Children's Forum is a social institution established since 2012 and its existence was officially recognized by the local government of Siak and under the auspice of Office of Women's Empowerment, Child Protection, Control Population and Family Planning (DP3APPKB). Currently, Siak Children's Forum has managed to establish 14 child forum at sub-district level, so that every district in Siak has had a child forum. Siak Children's Forum consists of representatives of various middle and high school children in 14 sub-districts in Siak.

Children's Forum Siak as children social institution is focusing its participation activities in the development of children's basic rights fulfillment consisting of four rights, namely the right to life, grow, being protected, and participation. In performing their activities of fulfilling children's rights, Children's Forum Siak is not doing it alone, but cooperate, coordinate and communicate with the government and the communities.
The role of communication is one factor that determines the success of development particularly in relation to community involvement (Sulaiman, Adhi Iman, Lubis, Djuara P, Susanto, Djoko, dan Purnaningsih, Ninuk, 2015: 368). Active participation of Siak Children's Forum in disseminating programs relating to Child-Friendly Regency and becoming an institutional medium that holds the problem of youth is an important part indispensable in the success of Siak Regency for receiving the award of ChildFriendly Regency in Pratama category in 2013 and 2015, which then rises up to Madya category in 2017 from the Minister for Women Empowerment and Protection of the Republic of Indonesia.

Siak Children's Forum cohesiveness as a group in establishing communication becomes an integral and very important note to make Siak as a child-friendly district/regent Groups according to Mulyana (2008: 74 ) is a group of people who interact with each other to achieve a common goal, to know each other, and considers members of the group as part of the group. Communications group has a very complex function, such as to (1) maintain social relationships, (2) a forum for sharing knowledge (education), (3) to persuade the other members to do or not do something, (4) problem solving to make a decision, (5) a media therapy for specific individual to achieve his/her personal change (Bungin, 2008: 270).

Active participation, mutual love and care, as well as a cohesive communications network are number of indicators of a group or organization progress. Interaction through communication can equalize the perception, thereby building a cohesiveness or coherence of a group. Based on these descriptions, the focus of this article aims to reveal and analyze the forms of participation, cohesion and communication networks of FASI in running the programs set up as an effort of children's rights fulfillment in the development of childfriendly district in Siak.

\section{Research methods}

This study used qualitative methods with symbolic interaction approach to explaining the picture of group interaction and communication of Siak Childrens' Forum in actualizing the development of child-friendly city in Siak regency. Qualitative research is research that utilizes open interview to examine and understand the attitudes, views, 
feelings and behaviors of individuals or groups of people (Moleong: 2008: 5).

Through the symbolic interaction approach, this research seeks to understand the process, deeper meaning and commitment of Children's Forum to actualize Siak as child-friendly district by interpretation. The informants have been purposively chosen based on the criteria considered to fulfill the purpose of research. Informants in this study consists of: Chairman of the Siak Children's Forum (FASI), Member of Siak Children's Forum, Siak Children's Forum facilitator, Siak Trustees of Children's Forum, as well as parents of Siak Children's Forum members. Data were collected through interview, observation and documentation. Data analysis is done using components of data reduction, data presentation, drawing conclusion and verification. Bog quoted by Sugiyono (2016: 244) states that qualitative data analysis process is systematically finding and organize data obtained from observation which is easy to be understood and the findings can be informed to others. The quality or validity of research data is performed using triangulation techniques and the extension of participation.

\section{Children's Forum Profile Siak (FASI)}

In implementing a policy, commitment or willingness is a factor that can not be ignored. A strong commitment is a capital for the implementation of the policy ( Putera, 2015: 237). Through the development of child-friendly regency (KLA), Siak district government has made some real efforts to integrate children's rights issues into the planning and development toward childfriendly Siak regency. As a commitment to respond to an understanding of the importance of children's participation rights to create a world fit for children in the development, Siak district government establish and foster children's participation mediums (Children's Forum) which named the Siak Children's Forum (FASI).

Children's Forum Siak (FASI) was founded in 2012. Siak Children's Forum has a vision as a bridge in actualizing the fulfillment of children's participation, protection, equality, and development with the government of Siak. While the extended mission of Siak Children's Forum are: (1) the rights of children to be taken care of and being listened to; (2) put the interests of children for the sake of their development; (3) respect the expectations and participation of children in any form; (4) put the children's rights when dealing with the law and respect for children with special needs.

Siak Children's Forum consists of a Chairman, Vice Chairman, General Secretary, Daily Secretary, Treasurer, Advocacy Division, Division of socialization and Facilitation, Children's Rights Division of Inter-Agency Relations, Division of Arts and Culture and Sustainability Nations, Division of Development and Utilization of Information Technology, Potential Development Division, and Children and Environmental Protection Division. Siak Children's Forum membership consists of representatives from both children and groups of school children from 14 subdistricts in the region of Siak. Names of children's forum at district level in Siak are; (1) Children's Forum of Siak Subdistrict (FORMATION); (2) the Children's Forum of Menpura District (FAME); (3) Children's Forum of Bunga Raya subdistrict (Foray); (4) Children's Forum of Sabak Auh subdistrict (FASA); (5) Children's Forum of Apit River District (FANKESA); (6) Children's Forum of Pusako District (FAKO); (7) Children's Forum of Kandis District (Fakan); (8) Children's Forum of Minas District (Fanas); (9) Children's Forum of Tualang District; (10) Children's Forum of Mandau River (FANDAU); (11) Children's Forum of Dayun District (FANDAY); (12) Children's Forum of Lubuk District FALUD); (13) Children's Forum Koto of Gasib subdistrict (FANKOGA); (14) Children's Forum of Kerinci Kanan District.

Legally, Siak Children's Forum is under the auspices of DP3APPKB (Office of Women's Empowerment, Child Protection, Control Population and Family Planning) that directly serves as a companion in the various activities undertaken by Siak Children's Forum. DP3APPKB functions as a facilitator to oversee, assist and coordinate Siak Children's Forum. Any problems or obstacles perceived by Siak Children's Forum in making a program will be assisted by a facilitator to find a way out. In essence, Siak Children's Forum (FASI) serves as a pioneer and a reporting fulfillment of children's rights in Siak.

\section{Participation of Children's Forum in Implementing Policy of Child- Friendly Siak Regency}

Each program development will not be separated from the use of concept of communication-based on participation in carrying out the program, and the same 
thing is applied in the case of development policy program of child-friendly district (KLA). According to Rusidi (Akadun, 2011: 186), participation is the participation of a person in an activity held by the other party (groups, associations, government organizations, and so forth), in which participation is expressed or manifested in the form of effusion, outpouring of material (funds) and power outpouring in accordance with the expectation of the activity. Participation is required to achieve the success of the program in which participation is intended to improve the quality of development planning.

Since the establishment, Siak Children's Forum has participated in the implementation of district development program policy of Siak child-friendly with the principle of commitment, integrity, and support in various forms of participation. In the process of development in Siak Regency, Siak Children's Forum annually involved in a Public Consultation Forum meeting and the Development Planning Meeting (Musrenbang) in short term, medium term and long term, as a vehicle for children to express their opinions for the development process of child-friendly. Siak Children's Forum has a role as children's representative who will deliver voice, opinions, ideas, wishes, needs, and interests of children in Siak. This was expressed by the Chairman of Siak Children's Forum as follows:

"We've always invited to participate in musrenbang, so before that we usually gather together and have a discussion agenda issues related to children which become the most talked at the moment. Actually, the theme of discussion would not get too far from, for examples, how children get protection from violence in school, or how is the child crime all about. If there is a discourse or the latest official policy on children in the City of Siak, it will also be discussed. This is one of the child's participation in the viewing of the policy. We will do some brainstorming and the results points will become "Voice/ opinion of Siak Children ", which would be delivered on the forums or we also submit it to the Public Consultation Forum held at the Regent Office ". (Results Interview with Restu as Chairman of FASI, June 2017).).

Representatives of children who attend Musrenbang will bring the formulation of children's voices in Siak named "Voice of Siak's Children," contains the aspirations of children in Siak district on the fulfillment of children's rights in development. Principles built on these activities is the willingness of adults both government and stakeholders to hear the voices of children and considered them in the decision-making of development. In this regard, the Government of Siak has developed a Regional Action Plan (RAD) for the implementation of child-friendly districts development.

In terms of supporting the actualization of children's right to grow up, Siak Children's Forum submitted suggestions of building facilities and public space, the realization of inclusion in public school, information on child-friendly public spaces, child-friendly integrated spaces, etc to local government at Musrenbang and RPJMD (Regional MediumTerm Development Plan). Maharatu Fountain Park, Tunku Aminah Syarifah Park, Tengku Agung Park, and Traffic Park as public spaces in Siak are some form of realization of aspirations of Siak Children's Forum implemented by local governments.

\begin{abstract}
"We always prepare anything which indeed important for children's proper growth and blossoms, such as supportive facilities and public places. We deliver that in musrenbang and RPJMD will conduct an assessment and thereafter if it is approved, it will be realized by the government. Usually, when we submit ideas at musrenbang this year, the realization will take place in next year. It would take much longer time if we do that at RPJMD since it is a long-term plan (5 years), which different than musrenbang that done it once a year." (Interviews with Restu, Chairman of FASI in March 2017).
\end{abstract}

Siak Children's Forum interaction with environment raises collective consciousness to take part in social participation as the fulfillment of children's rights in Siak Regency. Siak Children's Forum actively organizes fundraising and relief for disaster victims through posts in schools and cooperates with Sub-district Children's Forum in Siak; the activity they called Love Cord Activities of Siak Children's Forum. The presence of Siak Children's Forum has also been able to take a role in helping to reduce the number of violence cases against children and to collect data on children who do not get a decent educational and teaching. Siak Children's Forum also encourages the emergence of tolerance between groups of children in localizing children's social problems and 
making it easier for local governments to find solutions, as Siak Children's Forum facilitator revealed:

\begin{abstract}
"Our participation also help the government to fulfill the rights of children directly down to the street children, children with special needs (ABK), and other children's issues. We record it, then we help the government to do the follow-up. We also supervise the problem-solving process to examine whether the government has already done the following up or has not. "(interview with Nofrianto, facilitator FASI, August 7th, 2017)
\end{abstract}

The attendance of Siak Children's Forum is not only for involving in the development process but also for providing benefits for the children. Siak Children's Forum also prepare the facility to develop talents, interests, and the ability to organize themselves according to the conditions of children with the intention that all communities in the district of Siak recognizes and guarantees the children's presence and activities in the region.Children's Forum Siak is a medium of participation in delivering and developing children's talents, such as Zapin ( Siak Malay traditional dance), requited rhymes, poetry talent and other talents. All forms of Siak Children's Forum participation is the illustrations that Siak always try to become a child-friendly city and make the children of this nation have potentials for their future.

\section{Communication and Cohesiveness of Siak Children's Forum}

Cohesiveness in a group is an important thing because it can be a unifying tool for group members to form an effective group. Group cohesiveness is formed from a variety of things, ranging from how the group was formed until things that make the group familiar (Irwanti, M., \& Muharman, D., 2015: 251). From the answers of informants of Siak Children's Forum members, it can be concluded that the high-intensity meeting, team communication, confidence, ability to solve problems, a sense of family and familiarity showed by members of Siak Children's Forum and the facilitators become fundamental reasons for children to be interested in Siak Children's Forum and join the forum.

The active role of children in Siak Children's Forum is a representation of children's devotion to the nation that deserves appreciation. When other children of their age are spending their time playing and having fun, these members of Siak Children's Forum would prefer to get together, discuss and exchange opinions about the programs they can plan in the framework of the fulfillment of child rights. Interaction and communication established in the Siak Children's Forum are not only performed face to face but also virtually through various activities to demonstrate its existence to the environment and maintaining kinship between members. Activities undertaken are formal and informal..

The intensity of face to face communication conducted by Siak Children's Forum occurs at moments of formal and informal activities in the form of regular meetings and sharing activity, training and motivation, as well as talent development activities, and the appreciation of art and culture. Activities of regular meetings aimed at familiarizing, make a closer relationship between internal and external parts of Siak Children Forum members, and is one of the activities to strengthen children's forums, such as coordination meeting and evaluation. KAMSIA agenda (stands for Thursday afternoon) is regular meeting agenda carried out by Siak Children's Forum which started after they come home from school. Agendas held are to greet members in the friendly meeting, to discuss the work program, to evaluate the activities, and to spend their free time after school by doing recreational activities.

Training activities (training) or socialization aims to strengthening the capacity of members of Siak Children's Forum and enhance the competence and capacity of members either individually or groups (organizations), such as facilitators' training for members age 18 and socialization of the role of children's forum and FASI Goes to Prison event as an activity that provide benefit to Children Against the Law (ABH) which is done by Siak Children's Forum to Subdistrict Children's Forum. Siak Children's Forum gives them learning through the study of group dynamics, motivation, and etc. The activities development based on interests and talents as well as an appreciation of art and culture are aimed to publicize the existence of members by displaying some of the performances created by the Siak Children's Forum members. In this form of activity, active Siak Children's Forum held a competition on childrens' talents in 
national holidays such as Anniversary of Independence, Siak's Birthday, Mother's Day, National Children's Day, and so forth. In all of its activities, Siak Children's Forum aided by Children's Forum Siak Companion of DP3APPKB Siak..

The intensity of interaction and communication of Siak Children's Forum is also done through virtual communication or communication online, and make good use of existing social networks to communicate with each other such as, sharing of information and sharing on WhatsApp group of Siak Children's Forum, Facebook Group Siak Children's Forum,Twitter.com@forumanaksiak, http:// fasiak.blogspot.co.id, and Instagram @ forumanaksiak. Through this virtual communication, Siak Children's Forum can increase the intensity of communication either with the purpose of discussing things or just say hello to each other, without having to be burdened with the distance between one district with other districts.

"Now is an advanced age so we do something advances with FASI.we use Line, Whatsapp and BBM, but there is only few people are using BBM nowadays. We have an idea to gather members of the 14 districts into one group of Siak Children's forum in social media. Almost all members (99\%) has joined us, but there are some who have not joined yet because they have constraints with their cellphones. Even though, we would forward them important text messages, and through that group we feel free to express ourselves and do discussion". (interview with Aldhimas, rom FALANG (Childrens' Forum of Tualang district) 7 Agustus 2017).

Prior to the meeting or face to face meetings, members are usually have scheduled and disseminated such information in advance to the group of social media they are in, like Whatsapp group. Within this group, members of FASI do not just talk about formal programs, but also about simple things like spreading the latest information, new exciting things experienced by members, and sometimes there are typical of FASI healthy jokes within the group without compromising the essence of the group's existence.

"This group is crowded and rarely quiet. There are always something to talk about, even though only for sharing typical funny jokes of ours since we have been closed to each other and have no hesitation in sharing everything. But still it does not diminish the initial group functions anyway. This is the group where we discuss issues or problems which probably occur at subdistrict group and regency's group members are here to help". (Interview with Muhammad Ikhsan, Siak District, August 5, 2017)

Communications group develops in line with the development of communication technology to overcome the distances that can not be reached simply by speaking in a normal range. The rapid development of technology, especially in the fields of communication, allows communication to occur every time with a very wide range and can involve anyone. The use of technology and such media communication has become a staple of the communicators today because essentially everyone concerned to establish a harmonious relationship with others using relevant media (Muslim, 2010: 116).

In communicating, Siak Children's Forum members use a special greeting to the members. Greetings of "Elders", "Childhood aging" refers to those members who have passed the age of 18 years, and greeting of "Ayah (father)", "Bunda (mother)", and "Abah (grandfather) addressed to the instructors of Siak Children's Forum. It is not intended to distinguish the status between members but used as an effort to approach one another and get a closer relationship. There are no formal rules in this children's forum to facilitate communication. A member can communicate with anyone, about anything, as long as it does not violate the rules and norms of decency that apply

According to Wiryanto (2005:50) cohesiveness is the strength of interaction from members of a group. Cohesiveness is shown in the form of hospitality between members of the group and they usually happy for being together. Each member are free to express their opinions and suggestions. Group members usually enthusiastic about what they are doing and willing to sacrifice personal interests for the sake of the group. They are willing to accept responsibility for the activities undertaken to meet the obligations. All of it shows the unity, cohesion and mutual pull of the group members. It is also happened in Siak Children's Forum group membership where there are hospitality among members; members are happy to get together; every member has the freedom to express his/her 


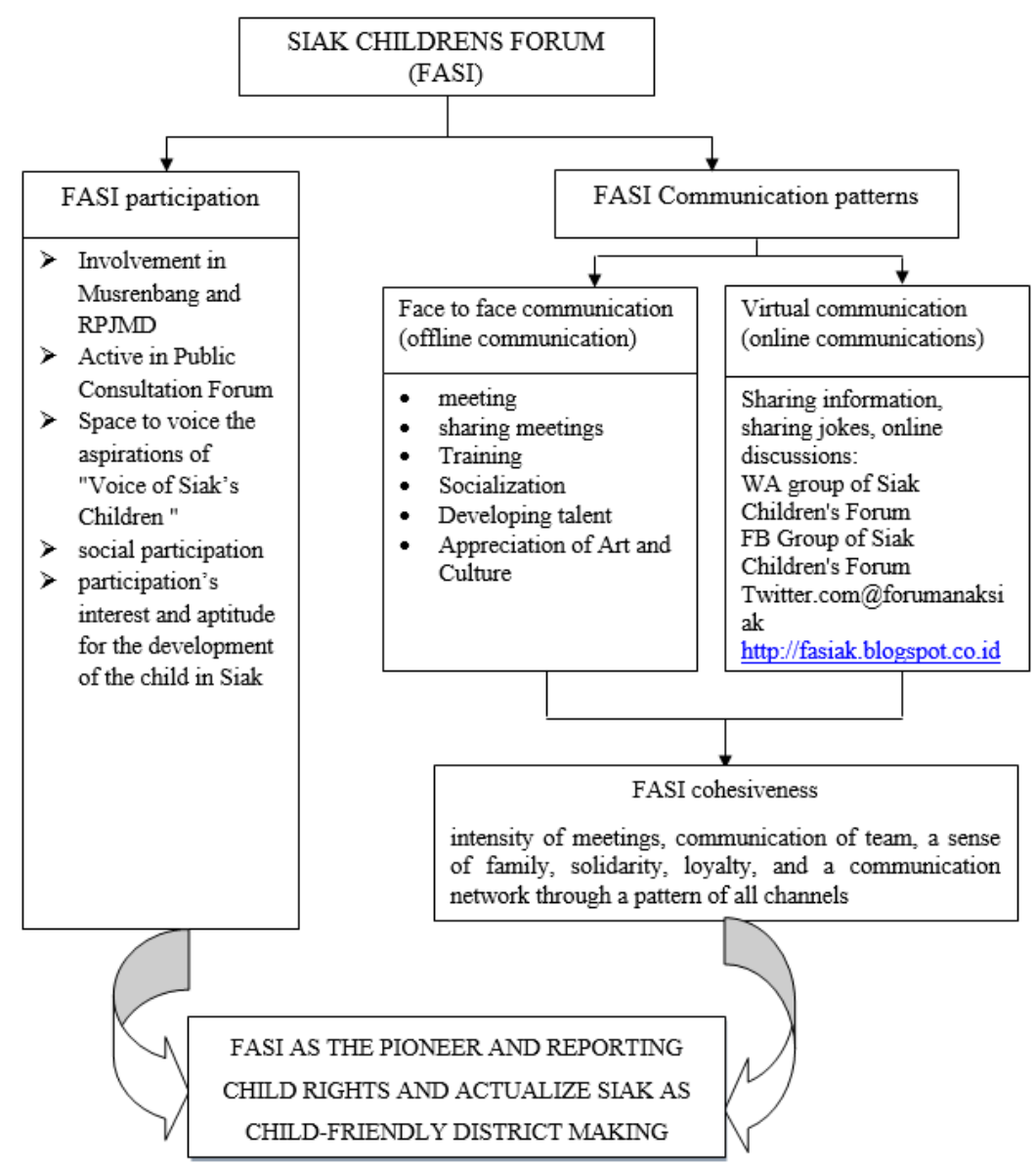

Figure 1

Communication Model of Siak Children's Forum Cohesiveness

opinions and suggestions; each member also enthusiastic about what he/she is doing for the group, and accept responsibility for the activities undertaken to meet its obligations and liabilities together. The problem often experienced by Siak Children's Forum is the limited availability of funds to run activities or working programs, though it did not become an obstacle for them to keep being pro-active and run their program of work that has been scheduled before.

\section{Communication Network in Siak Chil- dren's Forum Group Cohesiveness}

The communications network according to Rogers and Kincaid are individuals connected with one another by the communication flow pattern. It shows the essence of human behavior that interacts through the exchange of information between one individual and another in a system (Hapsari, 2016: 27). Based on observations and interviews conducted by the researcher,
Siak Children's Forum uses all channels of communication networks in conducting both virtual and face to face communication. In the pattern of all channels communication network, every member can communicate and get feedback from/reciprocate with other members (Andriawati, 2016:231). Although the Siak Children's Forum have structure and level of Chairman of the Forum, the Facilitator, and District Chairman and members, each member of Siak Children's Forum have the same power in communication. It is just that they still have to appreciate and knowing position of their leaders, namely the Chairman of Siak Children's Forum, and communications occur in the two-way system. Siak Children's Forum always assumes that their membership is like a family.

"Just like a family, that is what FASI is trying to instill in member, so that every member of the family is free to express anything he/she wanted to say, there is no need to be afraid and we try to be equal without one being powerful than 
the others. We do not want to be rigid, we love to chat in fun way, being cohesive and do intense communication with one another ". (Interview with Salman Abdul Ghani, Chairman Fanas (District of Minas Children's Forum), on August 7, 2017).

In a face to face discussion which was attended by the facilitator, all members, chairman of Siak Children's Forum, as well as chairman of children's' forum from various districts in Siak, children of members can directly express their opinions and thoughts to the forum without considering the existing structure and will get straight response from forum's participants. Every input from members will always be accommodated and discussed openly before finally do the followup on those inputs. The facilitators only serve as a companion of the ongoing discussions and there are no special requirements for members to be able to communicate directly with the facilitators. Facilitator position is comparable to an older brother in a family.

\begin{abstract}
"In every meeting, all of our members are always invited to speak, we consulted only when they have finished discussing the surface and half toward the core issue. They let us know what they think, they discussed an input of solution. If there are inputs or feedback that needs to be fixed/revised, we try to direct them. If it is already appropriate, then we will support the follow-up and if we think they need revision, we try to direct them. But advice we get from FASI founders uttered that any writing or aspirations of the children should not be changed, in the sense that the facilitator does not need to improve it and let the results sent to a Regent. This will be a learning experience for them that they do not have to go through the structure if they want to speak up in a meeting ". (Interview with Nofrianto, FASI facilitator, August 7th, 2017)
\end{abstract}

The pattern of all channels communications networks shaped the cohesiveness in children's forum. Cohesiveness formed in this children's forum somewhat influenced by the membership and role of each member, their good traditions and customs in communicating or interacting, their awareness of each member on their functions and structure of the forum, as well as attachment created from interaction and communication among members.

The research results and discussion above are simply described in a model of communication of Siak Children's Forum cohesiveness in realizing Child-Friendly Regent that can be seen in figure 1 .

\section{Conclusion}

Siak Children's Forum (FASI) is an organization of children's participation and representation of children's voice in the development process of Siak. Forms of participation of Siak Children's Forum in the fulfillment of children's rights in Siak Regency are ideas, social participation, and participation in the development of their interests, talents and appreciation of art and culture. Group cohesiveness of Siak Children's Forum formed among members through the intensity of interactions that occur in the form of face to face communication and virtual communication through a variety of activities that demonstrate its existence to the environment and maintaining kinship among members. Communication pattern of Siak Children's Forum in a form of all channels communication network helped establish cohesiveness in Siak Children's Forum. A communication without formal rules make them do intensive interaction and create close relationship, familiarity, and respect/ protective to each other as a commitment of being a pioneer and reporter of actualization process of child-friendly development in Siak Regency.

It is suggested to local governments, businesses, communities and families to build a situation that takes into account the fulfillment of children's rights together, and also the protection of children because they are the assets that will continue the development of this nation. The response and very positive support from various parties on the existence of Siak Children's Forum make it more cohesive, enthusiastic, passionate and intelligent in conducting various activities in favor of the best interests of the children

\section{References}

Akadun. (2011).Revitalisasi Forum Musrenbang sebagai Wahana Partisipasi Masyarakat dalam Perencanaan Pembangunan Daerah. Mimbar, Vol. 27, No. 2, hal. 125-240.

Andriawati, Maria Regina. (2016). Jaringan Komunikasi Perantau Etnis Jawa Asal Banyuwangi di Kota Makassar Terhadap Daya Tarik Daerah Tujuan dan Daerah 
Asal. Jurnal Komunikasi KAREBA, Vol. 5, No.1, hal.1-245

Bungin, B. (2008). Sosiologi Komunikasi. Komunikasi (Teori, Paradigma, dan Discourse Teknologi Komunikasi di Masyarakat). Jakarta: Kencana Prenada Media Group

Deputi Tumbuh Kembang Anak Kementerian Pemberdayaan Perempuan dan Perlindungan Anak, RI. ( 2012). Pedoman Pengembangan Forum Anak. Jakarta

Hapsari, Dwi Retno. (2016). Peran Jaringan Komunikasi Dalam Gerakan Sosial untuk Pelestarian Lingkungan Hidup. Jurnal Komunikasi Ikatan Sarjana Komunikasi Indonesia. Vol. 1, No. 1, hal 1-70.

Irwanti,M.,\& Muharman,D.,(2015). Perspektif Baru Groupthink: Perbedaan Tingkat Pendidikan dalam Proses Pengambilan Keputusan Kelompok. Mimbar. Vol.31, No.1, hal. 1-262

Kementerian Negara Pemberdayaan Perempuan dan Perlindungan Anak Republik Indonesia.(2012). Peraturan Menteri Negara Pemberdayaan Perempuan dan Perlindungan Anak Republik Indonesia Nomor 03 Tahun 2011 Tentang Kebijakan Partisipasi Anak Dalam Pembangunan, Jakarta.
Moleong, Lexy J. (2008). Metodologi Penelitian Kualitatif. Bandung: PT Remaja RosdakaryaOffset.

Mulyana,Deddy. (2008). Ilmu Komunikasi Suatu Pengantar. Bandung: PT Remaja Rosdakarya.

Muslimin. (2010). Teknologi Media Modern dan Upaya Mempertahankan Kebudayaan. Jakarta:Erlangga

Putera, Roni Ekha, (2015). Implementasi Kebijakan Otonomi Daerah Bidang Pendidikan dalam Pencapaian "Millennium Development Goals". Mimbar, Vol. 31, No. 1 , hal.1-262.

Sugiyono. (2016). Metode Penelitian Kuantitatif, Kualitatif). dan R\&D. Bandung: PT Alfabet.

Sulaiman, Adhi Iman., Lubis, Djuara P., Susanto, Djoko., \& Purnaningsih, Ninuk. (2015). Komunikasi Stakeholder dalam Musyawarah Perencanaan Pembangunan (Musrenbang). Mimbar. Vol. 31, No. 2, hal. 367-378

Wiryanto. (2005). Pengantar Ilmu Komunikasi. Jakarta: Gramedia Widiasarana Indonesia

Yustikasari, Rosfiantika.(2012). Komunikasi Empati Melalui Pelaksanaan. Program Kota Layak Anak. Bandung : Jurnal Kajian Komunikasi. LP3 UNPAD Vol.1, No.1, Desember. 